\title{
Contributing Authors and Participants in Discussions
}

Prof. Dr. G. Asboe-Hansen, Department of Dermatology, University of Copenhagen

Rigshospitalet

COPENHAGEN, 9, Blegdamsvej, Denmark

Dr. B. W. Barry, Portsmouth Polytechnic, School of Pharmacy PORTSMOUTH PO1 2DZ, King

Henry I Street, Great Britain

Prof. Dr. E. H. Beutner, Department of Microbiology, State University of New York BUFFALO, NY 14214, 219 Sherman Hall, USA

Dr. H. Brodthagen, The Finsen Institute, Department of Dermatology COPENHAGEN, 49, Strandboulevarden, Denmark

Prof. Dr. C. D. Calnan, St. John's Hospital for Diseases of the Skin LONDON WC2 H7BJ, Leicester Square, Great Britain

Prof. Dr. R. H. Cormane, University of Amsterdam, Department of Dermatology

Binnengasthuis

AMSTERDAM, Grimburgwal 10, The Netherlands

Dr. J. Dabrowski, Department of Dermatology, Medical School WARSAW, ul. Koszykowa 82a, Poland

Dr. A. Dobozy, Department of Dermatology, University Medical School SZEGED, Korányi

Fasor 8-10, Hungary

Dr. J. de Flines, Member of the Board of Management of Gist-Brocades NV DELFT,

Wateringseweg 1, P.O. Box 1, The Netherlands

Mrs. Dr. É. Fülöp, Department of Dermatology, Semmelweis Medical University 1085

BUDAPEST, Maria u. 41, Hungary

Dr. P. M. Gaylarde, The Royal Free Hospital

LONDON NW3 2QG, Pond Street, Hampstead, Great Britain

Dr. M. J. Th. H. Go, De Wever Hospital HEERLEN, Henri Dunantstraat 5, The Netherlands 274

Mrs. Dr. M. Groniowska, Department of Dermatology, Medical School WARSAW, ul.

Koszykowa 82a, Poland

Prof. Dr. Cí. Grupper,

75008 PARIS, 38, Rue Courcelles, France

Dr. L. G. I. Hellgren, Hudkliniken Sahlgrenska Sjukhuset GÖTEBORG S 41345, Sweden

Dr. W. Hespe, Biological Research and Development Gist-Brocades NV DELFT, P.O. Box 1,

The Netherlands

Dr. B. H. R. Hill,

NAPIER, T. \& G. Building, Marine Parade, Box 61, New Zealand

Dr. G. Holti, The Royal Victoria Infirmary NEWCASTLE upon TYNE NE1 4 LP, Great Britain

Dr. K. D. Jaitly, Biological Research and Development Gist-Brocades NV DELFT, P.O. Box 1,

The Netherlands 
Prof. Dr. S. Jabloñska, Department of Dermatology, Medical School WARSAW, ul. Koszykowa 82a, Poland

Mr. B. L. van Kan, Biological Research and Development Gist-Brocades NV DELFT, P.O. Box 1 , The Netherlands

Dr. P. D. C. Kinmont, Department of Dermatology, General Hospital NOTTINGHAM NG1

6HA, Great Britain

Prof. Dr. K. Király, Department of Dermatology, Semmelweis Medical University 1085

BUDAPEST, Maria u. 41, Hungary

Prof. Dr. Dr. H. E. Kleine-Natrop, Dermatological Clinic of the 'Carl Gustav Cams'

Medical Academy

8019 DRESDEN, Fetscherstrasse 74, GDR

Prof. Dr. H. Kõda, Department of Dermatology, Faculty of Medicine FUKUOKA, Kyushu University, Japan

Prof. Dr. A. Kukita, Department of Dermatology, Faculty of Medicine, University of

Tokyo

TOKYO 113, 3-1, Hongo 7-Chome, Bunkyo-ku, Japan

Dr. W. Maciejewski, Department of Dermatology, Medical School WARSAW, ul. Koszykowa 82a, Poland

Prof. Dr. Howard I. Maibach, University of California, Medical School SAN FRANCISCO, CA 94143, USA

Dr. R. Marks, Department of Medicine, The Welsh National School of Medicine,

University of Wales

CARDIFF, CF4 4XN, Heath Park, Great Britain

Dr. D. D. Munro, St. Bartholomew's Hospital LONDON EC1, West Smithfield, Great Britain

Prof. M. M. Nada,

CAIRO, 183, El Tahre Street, El Falaky Square, Egypt

Dr. P. C. H. Newbold, Worcester Royal Infirmary WORCESTER WR1 3AS, Castle Street

Branch, Great Britain

Dr. A. H. Nieuwmeuer,

AMSTERDAM, Haringvlietstraat 21, The Netherlands

Prof. Dr. M. K. Polano, Department of Dermatology, University Hospital LEYDEN,

Rijnsburgerweg 10, The Netherlands

Mrs. Dr. M. Ponec, Department of Dermatology, University Hospital LEYDEN, Rijnsburgerweg 10, The Netherlands

Prof. Dr. A. Querido, University Hospital LEYDEN, Rijnsburgerweg 10, The Netherlands

Dr. W. Raab, Department of Medical Chemistry, Vienna University A-1090 VIENNA,

Währinger Strasse 10, Austria

Dr. N. R. Rowell, Department of Dermatology, The General Infirmary LEEDS LSI 3EX, Great

Britain

Dr. I. Sarkany, The Royal Free Hospital

LONDON NW3 2QG, Pond Street, Hampstead, Great Britain

Dr. J. A. Savin, Department of Dermatology, The Royal Infirmary EDINBURGH EH3 9YW,

Scotland, Great Britain

Prof. Dr. rer.nat. H. Schaefer, Hautklinik der Freien Universität im Rudolf-Virchow-

Krankenhaus FB3, WE15, 1000 BERLIN 65, Augustenburger Platz 1, GFR 
Prof. Dr. H. Schmidt, Department of Dermatology, Odense University Hospital DK.-5000

ODENSE, Denmark

Prof. Dr. N. Simon, Department of Dermatology, University Medical School SZEGED, Korányi

RKP. 8-10, Hungary

Dr. I. B. Sneddon, Rupert Hallam Department of Dermatology, Hallamshire Hospital

SHEFFIELD S10 2JF, Glossop Road, Great Britain

Mrs. Dr. Gy. Soós, Department of Dermatology, Semmelweis Medical University 1085

BUDAPEST, Maria u. 41 , Hungary

Dr. T. W. Stewart, Liverpool Royal Infirmary LIVERPOOL L3 5 PU, Pembroke Place, Great

Britain

Dr. R. B. Stoughton, Scripps Clinic and Research Foundation, Division of Dermatology LA

JOLLA, CA 92037, USA

Prof. Dr. G. Stüttgen, Hautklinik der Freien Universität im Rudolf-Virchow-Krankenhaus FB3

WE15, 1000 BERLIN 65, Augustenburger Platz 1, GFR

Dr. Y. Takeda, Department of Dermatology, Sapporo Medical College SAPPORO, Hokkaido, Japan

276

Dr. J. Thormann, The Finsen Institute, Department of Dermatology COPENHAGEN, 49,

Strandboulevarden, Denmark

Dr. E. A. Tschen,

GUATEMALA, 4 Av. 16-71 Zona 10, Guatemala, Central America

Prof. Dr. H. Urabe, Department of Dermatology, Faculty of Medicine, Kyushu University

FUKUOKA, 3-1-1, Maedashi, Higashi-ku, Japan

Dr. D. J. H. Vermeer,

AMSTERDAM, Alb. Dürerstraat 30, The Netherlands

Dr. M. Walski, Department of Dermatology, Medical School WARSAW, ul. Koszykowa 82a, Poland

Dr. R. P. Warin, Bristol Health District (Teaching), Bristol Royal Infirmary BRISTOL BS2

8HW, Marlborough Street, Great Britain

Prof. Dr. G Weber, Skin Clinic, Nuremberg City Hospital D-8500 NUREMBERG, Flurstrasse 17, GFR

Dr. J. Wieriks, Biological Research and Development Gist-Brocades NV DELFT, P.O. Box 1, The Netherlands

Prof. Dr. E. Wilson Jones, The Institute of Dermatology LONDON WC2H 7BJ, Lisle Street,

Great Britain

Dr. J. Wuite, De Wever Hospital

HEERLEN, Henri Dunantstraat 5, The Netherlands

Dr. K. Yamada, Muroran-City Hospital, Section of Dermatology HOKKAIDO, Muroran, Japan

Prof. Dr. T. Yasuda, Department of Dermatology, School of Medicine, Toho University

TOKYO, 6-11-1, Omori-Nishi, Ohta-ku, Japan

ACKNOWLEDGEMENTS

The editors thank the following for help in producing the Proceedings: Mary Melvill van

Carnbee, Lineke Polak, Eveline Sleebos, Marjolein Statius Muller. 